\title{
Elloxazinones A and B, New Aminophenoxazinones from Streptomyces griseus Acta $2871^{\dagger}$
}

\author{
Ellen Graf, Kathrin Schneider, Graeme Nicholson, Markus Ströbele, Amanda L. Jones, \\ Michael Goodfellow, Winfried Beil, Roderich D. Süssmuth, Hans-Peter Fiedler
}

Received: March 7, 2007 / Accepted: March 22, 2007

(C) Japan Antibiotics Research Association

\begin{abstract}
Two new aminophenoxazinone compounds with antitumor activity, elloxazinone $\mathrm{A}$ and $\mathrm{B}$, were isolated from the culture filtrate of Streptomyces griseus Acta 2871. Their chemical structures were determined by mass spectrometry, NMR spectroscopy and X-ray analysis. Elloxazinones A and B showed a moderate inhibition of the proliferation of human cells from gastric adenocarcinoma in vitro but a strong inhibition of hepatocellular carcinoma cells whereas elloxazinone B strongly inhibited the proliferation of human breast carcinoma cells.
\end{abstract}

Keywords aminophenoxazinones, antitumor activity, Streptomyces, taxonomy, structure elucidation

\section{Introduction}

Strain Acta 2871 was isolated from a soil sample collected from a steel waste tip at Consett, County Durham (UK) and screened during the course of the ACTAPHARM project to detect novel bioactive secondary metabolites for pharmaceutical applications. Extracts from culture filtrates and mycelia were prepared following the growth of the strain in shake flask cultures using different complex media. The secondary metabolite profiles were evaluated by HPLC-diode array analysis and an in-house developed HPLC-UV-Vis database [2]. Two metabolites in the culture filtrate extract of the strain (Fig. 1) showed characteristic and congruent UV-visible spectra that differed from those of 867 reference compounds stored in the database, but exhibited a similarity to phenoxazinone-type compounds, such as actinomycins. The HPLC-ESI-MS analysis of the culture filtrate extract revealed a molecular mass of 313.1 for the compound with a retention time of 8.7 minutes and 299.1 for the compound with a retention time of 7.0 minutes. The compounds were named elloxazinone A (1) and elloxazinone B (2) respectively. These data did not correspond with those of other phenoxazinone-type pigments that are known to be widely distributed in nature, such as 2-aminophenoxazin-3-one (3) [3] from a streptomycete strain and three derivatives thereof isolated from a marine Halomonas strain [4], 2-ethanolamino-phenoxazin-3-one from a Streptomyces thioluteus strain [5], 2-amino-1-carboxy-phenoxazin-3one from a Nocardiaceae strain [6], texazone from an unidentified actinomycete strain [7], chandrananimycins from a marine Actinomadura strain [8], as the fungal pigments cinnabarin [9] and tramesanguin [10]. The
H.-P. Fiedler (Corresponding author): Mikrobiologisches Institut, Universität Tübingen, Auf der Morgenstelle 28, 72076 Tübingen, Germany, E-mail: hans-peter.fiedler@uni-tuebingen.de

R. D. Süssmuth (Corresponding author), E. Graf, K. Schneider (contributed equally): Institut für Chemie, Technische Universität Berlin, Straße des 17. Juni 124, 10623 Berlin, Germany,

E-mail: suessmuth@chem.tu-berlin.de

G. Nicholson: Institut für Organische Chemie, Universität Tübingen, Auf der Morgenstelle 18, 72076 Tübingen, Germany
M. Ströbele: Institut für Anorganische Chemie, Universität Tübingen, Auf der Morgenstelle 18, 72076 Tübingen, Germany

M. Goodfellow, A. L. Jones: Division of Biology, University of Newcastle, Newcastle upon Tyne, NE1 7RU, UK

W. Beil: Institut für Pharmakologie, Medizinische Hochschule Hannover, Carl-Neuberg-Str. 1, 30625 Hannover, Germany

† Art. No. 40 in 'Biosynthetic Capacities of Actinomycetes'. Art. No. 39: see ref. 1 


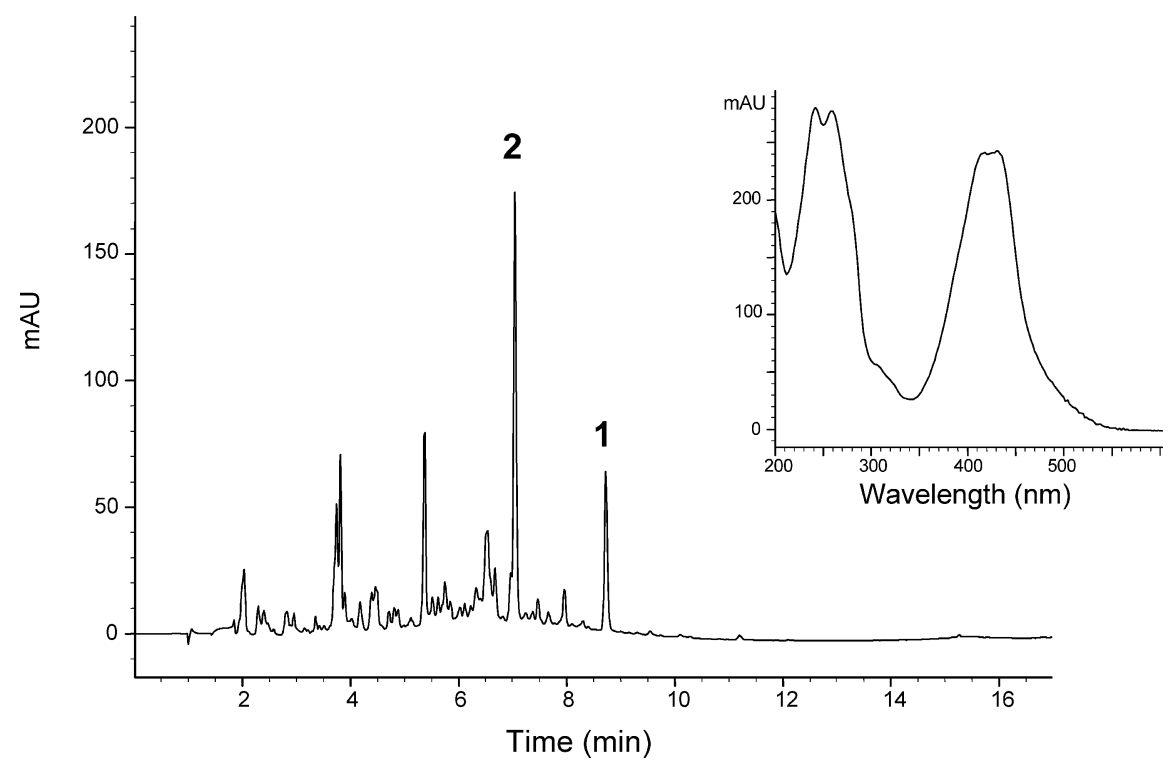

Fig. 1 HPLC analysis of a culture filtrate extract of Streptomyces griseus Acta 2871 at a fermentation time of 96 hours, monitored at $260 \mathrm{~nm}$, and UV-visible spectrum of elloxazinone B (2).

present work describes the fermentation, isolation and structure elucidation of elloxazinones and their biological activity.

\section{Materials and Methods}

\section{Producing Organism and Taxonomy}

Strain Acta 2871 was isolated from a soil sample collected from a steel waste tip at Consett, County Durham, UK. It was examined for a number of genotypic and phenotypic properties known to be of value in streptomycete systematics [11].

\section{Fermentation and Isolation}

Batch fermentations of strain Acta 2871 were carried out in a 10-liter stirred-tank fermentor (Biostat E, B. Braun Melsungen, Germany) in a medium that consisted of mannitol $20 \mathrm{~g}$ and soybean meal $20 \mathrm{~g}$ in 1 litre tap water. The fermentor was inoculated with $5 \%$ by volume of a shake flask culture grown in a seed medium at $27^{\circ} \mathrm{C}$ in 500 $\mathrm{ml}$ Erlenmeyer flasks with one baffle for 48 hours on a rotary shaker at $120 \mathrm{rpm}$. The seed medium consisted of glucose $10 \mathrm{~g}$, glycerol $10 \mathrm{~g}$, oatmeal $5.0 \mathrm{~g}$, soybean meal $10 \mathrm{~g}$, yeast extract $5.0 \mathrm{~g}$, casamino acids $5.0 \mathrm{~g}$ and $\mathrm{CaCO}_{3}$ $1.0 \mathrm{~g}$ in 1 litre tap water. The fermentation was carried out for 4 days with an aeration rate of $0.5 \mathrm{vvm}$ and agitation at $250 \mathrm{rpm}$.

Hyphlo Super-cel (2\%) was added to the fermentation broth which was separated by multiple sheet filtration into culture filtrate and mycelium. The culture filtrate was adjusted to $\mathrm{pH} 5$ with $5 \mathrm{M} \mathrm{HCl}$ and extracted three times with EtOAc; the organic extracts were combined and concentrated in vacuo to dryness. The crude product was dissolved in $\mathrm{CH}_{2} \mathrm{Cl}_{2}$ and added to a silica gel column $(45 \times 2.6 \mathrm{~cm}$, silica gel SI 60 , Merck). The separation was accomplished by a step gradient from $\mathrm{CH}_{2} \mathrm{Cl}_{2}$ to $5 \%$ $\mathrm{MeOH}$. Fractions containing $\mathbf{1}$ and $\mathbf{2}$ were combined and concentrated in vacuo to a small volume. Improved solubility of aminophenoxazinones was achieved by adding a few drops of ammonia to the concentrate which was purified by Sephadex LH-20 and Toyopearl TSK HW-40 chromatography (each column $90 \times 2.5 \mathrm{~cm}$ ) using $\mathrm{MeOH} / \mathrm{CH}_{2} \mathrm{Cl}_{2}(2: 1)$ as the eluent, a process that led to the separation of $\mathbf{1}$ and pure $\mathbf{2}$. In order to obtain pure $\mathbf{1}$ the raw product was subjected to preparative HPLC using a C18 column (Grom-Sil 300 ODS-5 St, $10 \mu \mathrm{m}, 2.0 \times 25 \mathrm{~cm}$ ) with $\mathrm{CH}_{3} \mathrm{CN} / 0.1 \% \mathrm{HCOOH}$ (a linear gradient from $65 \%$ to $80 \%$ $\mathrm{CH}_{3} \mathrm{CN}$ over 35 minutes) at a flow rate of $15 \mathrm{ml} /$ minute.

\section{HPLC-DAD Analyses}

The chromatographic system consisted of a HP 1090M liquid chromatograph equipped with a diode-array detector and a HP Kayak XM 600 ChemStation (Agilent Technologies). Multiple wavelength monitoring was performed at 210, 230, 260, 280, 310, 360, 435 and $500 \mathrm{~nm}$ and UV-visible spectra measured from 200 to $600 \mathrm{~nm}$. A $10-\mathrm{ml}$ aliquot of the fermentation broth was centrifuged, and the supernatant adjusted to $\mathrm{pH} 4$ and extracted with the same volume of EtOAc. After centrifugation, the 
organic layer was concentrated to dryness in vacuo and resuspended in $1 \mathrm{ml} \mathrm{MeOH}$. A $10-\mu 1$ aliquot of the sample was injected onto an HPLC column $(125 \times 4.6 \mathrm{~mm})$ fitted with a guard-column $(20 \times 4.6 \mathrm{~mm})$ filled with $5-\mu \mathrm{m}$ Nucleosil-100 C-18 (Maisch, Ammerbuch, Germany). The samples were analysed by linear gradient elution using $0.1 \%$ ortho-phosphoric acid as solvent A and acetonitrile as solvent $\mathrm{B}$ at a flow rate of $2 \mathrm{ml} /$ minute. The gradient was from $0 \%$ to $100 \%$ for solvent $B$ in 15 minutes with a 2 minute hold at $100 \%$ for solvent $\mathrm{B}$.

\section{Structure Elucidation}

LC-MS experiments were performed on an Applied Biosystems QTrap 2000 (Applied Biosystem, Darmstadt, Germany) coupled to an Agilent 1100 HPLC system (Agilent, Waldbronn, Germany). ESI-FT-ICR mass spectra were recorded on an APEX II FTICR mass spectrometer (4.7 T, Bruker-Daltonics, Bremen, Germany). NMR experiments were recorded on a DRX 500 NMR spectrometer (Bruker, Karlsruhe, Germany) equipped with a BBI probehead with $\mathrm{z}$ gradients.

A plate shaped red single crystal of $\mathbf{1}$, suitable for X-ray structure determination, was mounted on a glass fibre and measured on a Stoe IPDS I diffractometer, using graphitemonochromated Mo- $\mathrm{K}_{\alpha}$ radiation. The structure was solved by direct methods with SHELXS-97 and refined by leastsquares methods based on $F^{2}$ using SHELX-97 [12]. The non-hydrogen atoms were refined anisotropically. Hydrogen atoms were found in the difference electron density map and refined isotropically. The final $R_{1}$ and $w R_{2}$ values were 0.0538 and 0.0864 for reflections with $I>2 \sigma$, respectively.

Crystallographic data for the structure reported in this paper have been deposited with the Cambridge Crystallographic Data Center, CCDC, No. 634042. Copies of the data may be obtained free of charge on http:// www.ccdc.cam.ac.uk/products/csd/request.

\section{Biological Activities}

An agar plate diffusion assay was used to determine the antibacterial and antifungal properties of the elloxazinones produced by strain Acta 2871 using Arthrobacter aurescens DSM 20166, Bacillus subtilis DSM 10, Brevibacillus brevis DSM 30, Staphylococcus aureus DSM 20231 and Streptomyces viridochromogenes Tü 57 (Gram-positive bacteria) and Escherichia coli K12, Pseudomonas fluorescens DSM 50090 and Proteus mirabilis ATCC 35501 (Gram-negative bacteria). The yeasts and filamentous fungi examined were Candida albicans Tü 164, Saccharomyces cerevisiae ATCC 9080, Botrytis cinerea Tü 157 and Penicillium notatum Tü 136. Ten $\mu 1$ of the samples were applied to filter paper disks $(6 \mathrm{~mm}$ diameter), these were added to inoculated test plates that were incubated for 24 hours (bacteria) and 48 hours (fungi) at temperatures which allowed optimal growth of the test organisms.

The inhibitory activities of the elloxazinones on the growth of tumor cells was tested according to NCI guidelines [13] using human cell lines from gastric adenocarcinoma (AGS and HM02), breast carcinoma (MCF 7) and hepatocellular carcinoma (HepG2). Cells were grown in 96-well microtiter plates in RPMI 1640 with $10 \%$ fetal calf serum in a humidified atmosphere of $5 \% \mathrm{CO}_{2}$ in air. The aminophenoxazinones $\mathbf{1}$ and $\mathbf{2}$ $(0.1 \sim 10 \mu \mathrm{l} / \mathrm{ml})$ were added to the cells after incubation for 24 hours. Stock solutions were prepared in DMSO; the final DMSO concentration of the cultures was $0.1 \%$. The cells were fixed and cell protein assayed with sulforhodamine B after a 48-hours incubation.

Cell cycle distributions were determined by staining DNA with propidium bromide. AGS and MCF7 cells were treated for 24 hours with indicated concentration of 2, harvested by trypsination, washed with RPMI 1640 containing $1 \%$ fetal bovine serum and resuspended in $100 \mu \mathrm{l}$ staining solution (propidium bromide $150 \mu \mathrm{g} / \mathrm{ml}$, $4 \mathrm{mM}$ Na-citrate $\mathrm{pH} 7.0,1 \%$ Triton X-100, 1\% BSA). After 15 minutes incubation at room temperature in the dark, $100 \mu \mathrm{l}$ RNAse solution $(10 \mathrm{mg} / \mathrm{ml}$ Ribonuclease $\mathrm{A}$ in Tris/HCl buffer, $\mathrm{pH} 7.5$ ) were added. Thirty minutes later cells were analyzed using a Becton Dickinson FACSscan.

\section{Results}

\section{Taxonomy of the Producing Strain}

The presence of LL-diaminopimelic acid in whole-organism hydrolysates [14] together with its colonial properties [15] indicated that strain ACTA 2871 was a member of the genus Streptomyces. More detailed taxonomic studies showed that the organism had properties consistent with its assignment to Streptomyces griseus as it produced a grey aerial spore mass on oatmeal agar, formed straight to flexuous chains of smooth surfaced spores and shared very high 16S rRNA gene sequences (99.5 99.7\%) with members of this taxon [16].

\section{Fermentation and Isolation}

Strain Acta 2871 was grown in a 10-litre stirred tank fermentor using a complex medium. The culture reached a maximal biomass of $20 \mathrm{vol}-\%$ after 48 hours of incubation when elloxazinone production started. The highest yield of 1 was produced in $18 \mathrm{mg} /$ litre, and that of 2 in $48 \mathrm{mg} /$ litre after an incubation period of 96 hours. 1 and 2 were 
isolated from the culture filtrate by extraction with ethyl acetate and purified by subsequent chromatography on silica gel, Sephadex LH-20 and Toyopearl HW-40F and preparative reversed-phase HPLC. The elloxazinones were obtained as red powders after lyophilization.

\section{Structure Elucidation}

The HPLC-ESI-MS spectra revealed molecular masses for $1\left[(\mathrm{M}+\mathrm{H})^{+}=314.1\right]$ and $2\left[(\mathrm{M}+\mathrm{H})^{+}=300.1\right]$. The exact molecular masses were determined by high resolution ESI-FT-ICR-MS, as $314.0771\left[(\mathrm{M}+\mathrm{H})^{+}\right]$; 1 and $298.0470\left[(\mathrm{M}-\mathrm{H})^{-}\right] ; 2$, corresponding to the molecular formulae $\quad \mathrm{C}_{15} \mathrm{H}_{11} \mathrm{~N}_{3} \mathrm{O}_{5} ; \quad \mathbf{1}\left[(\mathrm{M}+\mathrm{H})^{+}{ }_{\text {theor }}=314.0771\right.$; $\Delta \mathrm{m}=0.098 \mathrm{ppm}]$ and $\mathrm{C}_{14} \mathrm{H}_{9} \mathrm{~N}_{3} \mathrm{O}_{5} ; \quad 2 \quad\left[(\mathrm{M}-\mathrm{H})^{-}\right.$theor $=$ 298.0469; $\Delta \mathrm{m}=0.19 \mathrm{ppm}]$.

The ${ }^{1} \mathrm{H}-\mathrm{NMR}$-spectrum of $\mathbf{1}$ showed nine signals, one in the aliphatic region, six signals in the aromatic region and two signals in the downfield region above $9 \mathrm{ppm}$. The correlation of ${ }^{1} \mathrm{H}-\mathrm{NMR}$-signals to the corresponding Catoms was carried out by the Heteronuclear Multiple Quantum Coherence (HMQC) NMR experiment. Together with the results of the integration of the signals in the ${ }^{1} \mathrm{H}$ NMR-spectrum, one $\mathrm{CH}_{3}$ and four aromatic $\mathrm{CH}$ groups were identified. Four signals in the ${ }^{1} \mathrm{H}$-spectrum could not be assigned to any $\mathrm{C}$-atom, therefore suggesting the presence of four heteroatom bound protons. Furthermore, the ${ }^{13} \mathrm{C}$-spectrum revealed ten quaternary $\mathrm{C}$-atoms, three with a chemical shift lower than $165 \mathrm{ppm}$. With regard to the UV-spectrum of $\mathbf{1}$, with absorption maxima at 239 ,
259,411 and $428 \mathrm{~nm}$, strong similarities were found to the UV spectrum of 3 (237, 412 and $431 \mathrm{~nm}$ ) [4]. Therefore, it was concluded that $\mathbf{1}$ was structurally related to 2-aminophenoxazin-3-one. The 2-aminophenoxazin-3-one core structure includes one $\mathrm{C}$ atom with a chemical shift lower than $165 \mathrm{ppm}$ [4]. Therefore the two additional $\mathrm{C}$ atoms of 1 with a chemical shift of 170.1 and $165.3 \mathrm{ppm}$ suggested a carboxylic acid, an amide or an ester group as substituents of the core structure. The substituents and substitution pattern at the 2-aminophenoxazin-3-one core structure were determined with the help of 2D NMR spectra. Regarding ring $\mathrm{C}$ of $\mathbf{1}$ (Fig. 2) which was considered first, the HMBC experiment provided the crucial information for the presence of a methylester attached to C-8 (Fig. 3). The connectivities from H-7 and $\mathrm{H}-9$ to $\mathrm{C}-12$ and from $\mathrm{H}-13$ to $\mathrm{C}-12$ together with the chemical shift of the $\mathrm{CH}_{3}$ group (52.2 ppm) and the coupling constants of the protons H-6, H-7 and H-9 (Table 1) gave evidence for the assignment of the ring $C$ structure and its substitution pattern respectively. Comparing the molecular formula of a hypothetical 8-methoxycarbonyl-2aminophenoxazin-3-one, $\mathrm{C}_{14} \mathrm{H}_{10} \mathrm{~N}_{2} \mathrm{O}_{4}$, with the molecular formula of $1, \mathrm{C}_{15} \mathrm{H}_{11} \mathrm{~N}_{3} \mathrm{O}_{5}$, it was concluded that one substituent attached to ring $\mathrm{A}$ was $\mathrm{CONH}_{2}$, which corresponds to a carboxamide. Finally, the constitution of ring A was determined by the H-H COSY spectrum and the HMBC spectrum. The H-H COSY spectrum revealed two spin systems, showing a correlation between the protons with the chemical shift of 8.19 and $10.55 \mathrm{ppm}$ and a

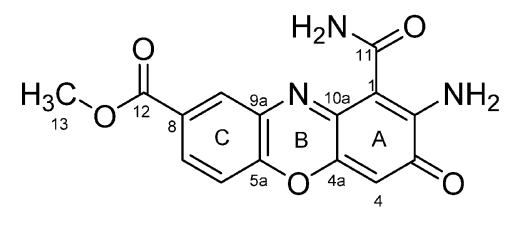

1

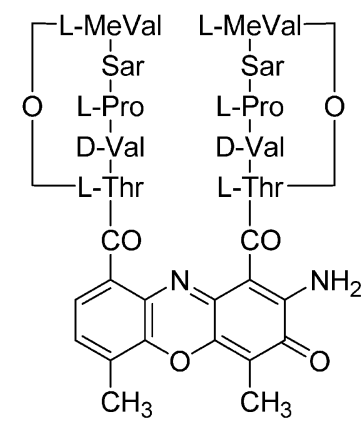

4<smiles>CC1=C2O[C@@H]3C=C(C(=O)O)C(N)=C(C(N)=O)[C@@H]3N=C2C=C1</smiles>

2<smiles>Cc1ccc2c(c1)OC1(C)CC(=O)C(N)=CC1=N2</smiles><smiles>CC(=O)NC(CSc1c2nc3cc(C(=O)O)ccc3oc-2cc(=O)c1N)C(=O)O</smiles>

Fig. 2 Structures of elloxazinones A (1), B (2), 2-aminophenoxazin-3-one (3), actinomycin D (4), 2-amino-4,4 $\alpha$-dihydro-4 $\alpha, 7$ dimethyl-2 H-phenoxazin-3-one (5), and grixazone B (6). 


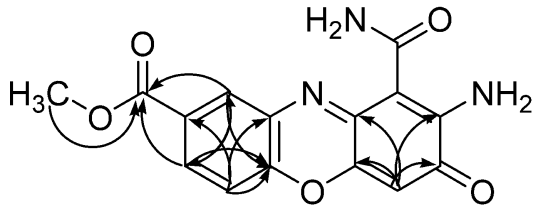

1

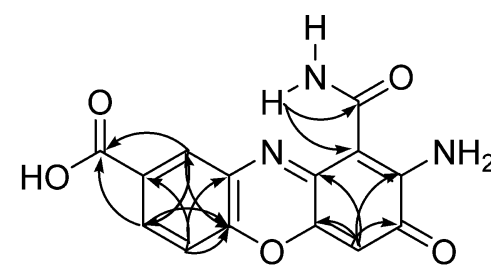

2

Fig. $3 \mathrm{HMBC}$ correlations for $\mathbf{1}$ and $\mathbf{2}$.

Table $\mathbf{1}{ }^{1} \mathrm{H}$ and ${ }^{13} \mathrm{C}$ NMR data of $\mathbf{1}$ and $\mathbf{2}$, and $\mathbf{3}$ [4]

\begin{tabular}{|c|c|c|c|c|c|c|}
\hline \multirow{2}{*}{ No. } & \multicolumn{2}{|c|}{1 in DMSO-d } & \multicolumn{2}{|c|}{2 in DMSO- $d_{6}$} & \multicolumn{2}{|c|}{3 in DMSO- $d_{6}$} \\
\hline & $\delta\left({ }^{1} \mathrm{H}\right)[\mathrm{ppm}](\mathrm{J}$ in $\mathrm{Hz})$ & $\delta\left({ }^{13} \mathrm{C}\right)[\mathrm{ppm}]$ & $\delta\left({ }^{1} \mathrm{H}\right)[\mathrm{ppm}](J$ in $\mathrm{Hz})$ & $\delta\left({ }^{13} \mathrm{C}\right)[\mathrm{ppm}]$ & $\delta\left({ }^{1} \mathrm{H}\right)[\mathrm{ppm}](J$ in $\mathrm{Hz})$ & $\delta\left({ }^{13} \mathrm{C}\right)[\mathrm{ppm}]$ \\
\hline 1 & - & 95.9 & - & 95.9 & $6.34, s$ & 98.4 \\
\hline 2 & - & $147.0^{\mathrm{a}}$ & - & $146.5^{a}$ & - & 148.8 \\
\hline 3 & - & 178.8 & - & 178.8 & - & 180.1 \\
\hline 4 & $6.55, \mathrm{~s}$ & 104.5 & $6.52, s$ & 104.1 & $6.37, \mathrm{~s}$ & 103.3 \\
\hline $4 a$ & - & $150.3^{\mathrm{a}}$ & - & $150.5^{\mathrm{a}}$ & - & 147.3 \\
\hline $5 a$ & - & 144.8 & - & 143.5 & - & 141.9 \\
\hline 6 & $7.60, \mathrm{~d}(8.64)$ & 116.1 & $7.50, \mathrm{~d}(8.56)$ & 115.1 & $7.48, \mathrm{dd}(8.0,1.5)$ & 115.8 \\
\hline 7 & $8.02, \mathrm{dd}(8.64,1.80)$ & 129.3 & 7.99, dd $(8.56,1.92)$ & 130.0 & $7.45, \operatorname{td}(8.0,1.5)$ & 128.7 \\
\hline 8 & - & $126.6^{b}$ & - & $131.1^{\mathrm{b}}$ & $7.38, \operatorname{td}(8.0,1.5)$ & 125.2 \\
\hline 9 & $8.44, d(1.80)$ & 128.8 & $8.30, d(1.91)$ & 128.5 & $7.69, \mathrm{dd}(8.0,1.5)$ & 127.9 \\
\hline $9 a$ & - & $131.5^{\mathrm{b}}$ & - & $132.8^{b}$ & - & 133.7 \\
\hline $10 a$ & - & $152.1^{\mathrm{a}}$ & - & $151.9^{a}$ & - & 148.2 \\
\hline 11 & - & 170.1 & - & 170.2 & - & - \\
\hline 12 & - & 165.3 & - & 167.0 & - & - \\
\hline 13 & $3.89, \mathrm{~s}$ & 52.2 & - & - & - & - \\
\hline 2-NH ${ }_{2}$ & $8.19 / 10.55$, brs & - & $8.09 / 10.43$, brs & - & $6.76, \mathrm{brs}$ & - \\
\hline $11-\mathrm{NH}_{2}$ & 7.63/9.83, s & - & 7.59/9.91, s & - & - & - \\
\hline
\end{tabular}

${ }^{a, b}$ Assignments bearing the same superscript may be exchangeable.

correlation between the protons with the chemical shift of 7.63 and $9.83 \mathrm{ppm}$ (Fig. 3). These protons could not be assigned to be bound to any $\mathrm{C}$-atom in the HMQC experiment and therefore it was assumed that two $\mathrm{NH}_{2}$ groups were substituents of ring A. The HMBC experiment showed strong correlations from $\mathrm{H}-4$ to $\mathrm{C}-2, \mathrm{C}-4 \mathrm{a}$ and C10a and a weak correlation to $\mathrm{C}-3$. One of the $\mathrm{NH}_{2}$ protons showed a correlation to $\mathrm{C}-1$, but no other correlation was observed. Based on these data it was not possible to clearly assign the chemical shifts $8.19 \mathrm{ppm} / 10.55 \mathrm{ppm}$ and $7.63 \mathrm{ppm} / 9.83 \mathrm{ppm}$ to a distinct $\mathrm{NH}_{2}$-group. Nevertheless, the assumption of an amide substituent at $\mathrm{C}-1$ in ring A was fully confirmed.

In parallel to NMR studies, crystallisation experiments were performed and for $\mathbf{1}$ a single crystal was obtained. Subsequent X-ray structure determination (Fig. 4) fully confirmed the constitutional formula shown in Fig. 2.

The comparison of the molecular formulae of $\mathbf{1}$, $\mathrm{C}_{15} \mathrm{H}_{11} \mathrm{~N}_{3} \mathrm{O}_{5}$, and $2, \mathrm{C}_{14} \mathrm{H}_{9} \mathrm{~N}_{3} \mathrm{O}_{5}$, suggested that 2 was the corresponding acid. This was supported by NMR data (Table 1). No signal for a methyl group was found in the ${ }^{1} \mathrm{H}$ NMR spectrum and in the ${ }^{13} \mathrm{C}$-spectrum spectrum. The observed correlations in the 2D NMR spectra were almost identical, but in the case of $\mathbf{2}$ the HMBC experiment revealed two connectivities for a proton of the $\mathrm{NH}_{2}$ group, to $\mathrm{C}-1$ and to $\mathrm{C}-11$. Therefore the $\mathrm{NH}_{2}$ group with the chemical shifts of 7.59 and $9.91 \mathrm{ppm}$ belongs to the amide group while the $\mathrm{NH}_{2}$ group with the chemical shifts of 8.06 
Table 2 Physico-chemical properties of $\mathbf{1}$ and $\mathbf{2}$

\begin{tabular}{lll}
\hline & \multicolumn{1}{c}{$\mathbf{1}$} & \multicolumn{1}{c}{$\mathbf{2}$} \\
\hline Appearance & Red solid & Red solid \\
Molecular weight & 313 & 299 \\
Molecular formula & $\mathrm{C}_{15} \mathrm{H}_{11} \mathrm{~N}_{3} \mathrm{O}_{5}$ & $\mathrm{C}_{14} \mathrm{H}_{9} \mathrm{~N}_{3} \mathrm{O}_{5}$ \\
ESI-FT-ICR MS $(\mathrm{m} / \mathrm{z})$ & & \\
Found & $314.0771(\mathrm{M}+\mathrm{H})^{+}$ & $298.0470(\mathrm{M}-\mathrm{H})^{-}$ \\
Calcd & 314.0771 & 298.0469 \\
UV $\lambda_{\max }^{\mathrm{MeOH}}[\mathrm{nm}](\log \varepsilon)$ & $239(2.73)$ & $240(2.12)$ \\
& $259(2.57)$ & $256(1.93)$ \\
& $411(2.07)$ & $412(1.42)$ \\
& $428(2.09)$ & $431(1.50)$ \\
\hline
\end{tabular}

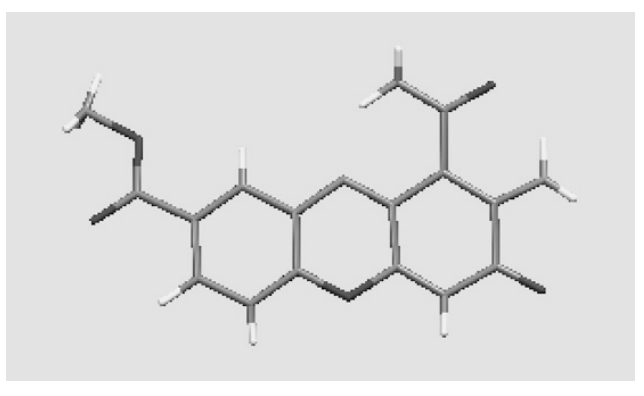

Fig. 4 X-Ray structure of $\mathbf{1}$

and $10.43 \mathrm{ppm}$ is the amine group attached to C-2. In analogy to the assignments of $\mathbf{2}$ we suggest the $\mathrm{NH}_{2}$ group with the chemical shifts of 7.63 and $9.83 \mathrm{ppm}$ of $\mathbf{1}$ to belong to the amide group.

In conclusion, 1 could unambiguously be identified as 2-amino-1-carbamoyl-8-methoxycarbonylphenoxazin-3-one, and $\mathbf{2}$ as 2-amino-1-carbamoyl-8-carboxyphenoxazin-3-one. Both compounds are structurally new 2-aminophenoxazin3-ones.

\section{Biological Activity}

1 and $\mathbf{2}$ did not show antibacterial or antifungal activity against any of the tested organisms. When the cytostatic effects of $\mathbf{1}$ and $\mathbf{2}$ were tested against various human tumor cell lines each of the compounds were found to inhibit the growth of HepG2 and MCF 7 cells at very low concentrations (Table 3), whereas the gastric cell lines HM02 and AGS were less sensitive.

The cell cycle analysis of AGS cells exposed to $5 \mu \mathrm{g} / \mathrm{ml}$ $\mathbf{2}$ is given in Table 4.2 locks the cells initially in the G1 phase. The percentage of cells in sub G1 phase was significantly increased, indicating apoptosis. In MCF 7 cells $2(0.01 \mu \mathrm{g} / \mathrm{ml})$ increased the number of cells in G1 by $4 \%$, and the number of cells in sub G1 by $2.6 \%$.

\section{Discussion}

The most prominent aminophenoxazinone antibiotics are the actinomycins, e.g. actinomycin D (4), yellow chromopeptides which were the first antibiotics discovered in streptomycetes [17]. Actinomycins form complexes with DNA and intercalate in the minor groove of helical DNA. Their high toxicity excluded them as antiinfective drugs for clinical use, but their tumorstatic properties led to intensive efforts in derivatization programs for investigations of structure-activity relationships [18]. Actinomycins have a characteristic substitution of the aminophenoxazinone chromophor in positions 1 and 9 with two side chains consisting of pentapeptide lactones (Fig. 2). Further substitutions of the chromophor are methyl groups in positions 4 and 6 . The functional groups of actinomycins which are indispensable for biological activity and complex formation with DNA are the amino group in position 2, an quinoidal oxygen in position 3 , and the intact, cyclic pentapeptide lactones in positions 1 and 9 [19]. All efforts to modify the amino acid composition of the peptide chain were without success as they did not increase the cytostatic activity or reduce the toxic properties of the molecule thereby leading to respiratory disorders and lesions in the kidneys, liver and spleen [20]. Replacement of the pentapeptide side chains by aminoalkyl side chains of variable length and different terminal groups strongly influences the antitumor activity [21].

In this context it is of particular interest to compare the antitumor activity of the aminophenoxazinones having a different substitution pattern than actinomycins. It has been reported that 3 inhibits the proliferation of mouse 
Table 3 Activity $(\mu \mathrm{g} / \mathrm{ml})$ of $\mathbf{1}$ and $\mathbf{2}$, and actinomycin D (4) against selected human tumor cell lines

\begin{tabular}{|c|c|c|c|c|c|c|c|c|}
\hline & \multicolumn{4}{|c|}{$\mathrm{GI}_{50}$} & \multicolumn{4}{|c|}{ TGI } \\
\hline & AGS & $\mathrm{HM} 02$ & HepG2 & MCF 7 & AGS & $\mathrm{HMO} 2$ & HepG2 & MCF 7 \\
\hline 1 & 6.5 & 3.8 & 0.075 & 2.0 & $>10^{a}$ & $>10^{b}$ & 8.9 & 9.8 \\
\hline 2 & 6.4 & 1.0 & 0.070 & 0.0065 & $>10^{c}$ & $>10^{d}$ & 1.0 & 0.0075 \\
\hline Actinomycin D & n.d. & 0.002 & 0.0015 & 0.0024 & n.d. & 0.008 & 0.0065 & 0.011 \\
\hline
\end{tabular}

$\mathrm{GI}_{50}: 50 \%$ growth inhibition; TGl: $100 \%$ growth inhibition; n.d.: not determined.

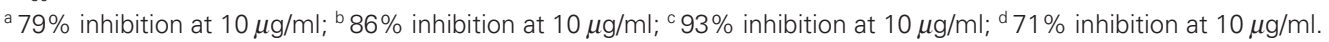

Table 4 Cell cycle analysis of AGS cells exposed to 2

\begin{tabular}{lcccc}
\hline Cell phase & $\begin{array}{c}\text { Sub G1 } \\
\text { (apoptose) }\end{array}$ & $\mathrm{G} 1$ & $\mathrm{~S}$ & $\mathrm{G} 2 / \mathrm{M}$ \\
\hline Control & $1.8 \pm 0.3$ & $51.6 \pm 1.5$ & $21.3 \pm 1.5$ & $24.3 \pm 0.4$ \\
$\mathbf{2}(5 \mu \mathrm{g} / \mathrm{ml})$ & $4.2 \pm 0.4^{*}$ & $62.0 \pm 0.7^{*}$ & $15.1 \pm 0.6^{*}$ & $18.2 \pm 0.1^{*}$ \\
\hline
\end{tabular}

Data represent percentage of cells in each stage of the cell cycle.

Values are mean $\pm S$. E. of three experiments. ${ }^{*} p<0.05$ versus control ( $t$ test).

malignant melanoma B16 cells in vitro, prevents the growth of melanoma cells transplanted into mice in vivo at extremely low concentrations, and causes only a few adverse effects on mice in contrast to 4 [22]. The synthetic aminophenoxazinone compound 2-amino-4,4 $\alpha$-dihydro$4 \alpha, 7$-dimethyl-2H-phenoxazin-3-one (5) was found to be a potent inhibitor of proliferation and an inducer of apoptosis in all leukemia cell lines showing few adverse effects in vivo [23]. It was shown that in contrast to 4 this type of aminophenoxazinone does not intercalate in DNA, but causes an arrest of the cells in the G1 phase and forces cells directly to apoptosis [24].

The recently described new aminophenoxazinones isolated from a marine Halomonas strain, 2-amino6-hydroxyphenoxazin-3-one and 2-amino-8-benzoyl-6hydroxyphenoxazin-3-one [4], showed moderate cytotoxic activity against different human tumor cell lines. The new aminophenoxazinones described in this paper, $\mathbf{1}$ and $\mathbf{2}$ from Streptomyces griseus Acta 2871, having an unusual substitution pattern of the core structure, exhibited a strong inhibition of human hepatocellular carcinoma cells; 2 very strongly inhibited human breast carcinoma cells. Only one other group of natural phenoxazin-3-one derivates, the grixazones A and B (6) produced by a Streptomyces griseus strain [25], have the same substitutions pattern, but different substituents, bearing a cysteine at C-1. Unfortunately there is no information available about their cytotoxic activity.

The cell cycle investigations in AGS and MCF7 cells showed that 2 locks the cells in G1 phase and induces apoptosis. One of the key regulatory system inducing apoptosis in tumor cells involves upregulation of the CD95 (APO-1/Fas) death receptor system [26]. Anticancer drugs induce different upregulation of the CD95 receptor in different human tumor cell lines (e.g. 5-fluoro uracil causes a weaker CD95 expression in AGS cells than in HepG2 cells) [27].

Acknowledgements This work was supported by the European Commission (project ACTAPHARM, 5th framework, grant QLK3-CT-2001-01783, and project ACTINOGEN, 6th framework, grant LSHM-CT-2004-005224) and by Schering AG (Berlin, Germany). The authors are grateful to Mr. G. Grewe and Dr. Andreas Reicke, Universität Tübingen, for technical assistance with the fermentations, and to Agilent Technologies (Waldbronn, Germany) for HPLC-software support.

\section{References}

1. Schneider K, Rose I, Vikineswary S, Jones AL, Goodfellow M, Nicholson G, Beil W, Süssmuth RD, Fiedler H-P. Nocardichelins A and B, new siderophores from Nocardia 
strain Acta 3026. J Nat Prod: accepted for publication

2. Fiedler H-P. Biosynthetic capacities of actinomycetes. 1. Screening for novel secondary metabolites by HPLC and UV-visible absorbance libraries. Nat Prod Lett 2: 119-128 (1993)

3. Anzai K, Isono K, Okuma K, Suzuki S. The new antibiotics, questiomycins A and B. J Antibiot 13: 125-132 (1960)

4. Bitzer J, Große T, Wang L, Lang S, Beil W, Zeeck A. New aminophenoxazinones from a marine Halomonas sp.: fermentation, structure elucidation, and biological activity. J Antibiot 59: 86-92 (2006)

5. Gerber NN. Phenazines, phenoxazinones, and dioxopiperazines from Streptomyces thioluteus. J Org Chem 32: 4055-4057 (1967)

6. Gerber NN. Phenazines and phenoxazinones from some novel Nocardiaceae. Biochemistry 5: 3824-3829 (1966)

7. Gerber NN, Yale HL, Taber WA, Kurobane I, Vining LC. Structure and syntheses of texazone, 2-( $N$-methylamino $)$ 3H-phenoxazin-3-one-8-carboxylic acid, an actinomycete metabolite. J Antibiot 36: 688-694 (1983)

8. Maskey RP, Li FC, Qin S, Fiebig HH, Laatsch H. Chandrananimycins $\mathrm{A} \sim \mathrm{C}$ : production of novel anticancer antibiotics from a marine Actinomadura sp. isolate M048 by variation of medium composition and growth conditions. J Antibiot 56: 622-629 (2003)

9. Gripenberg J. Fungus pigments. VIII. Structure of cinnabarin and cinnabarinic acid. Acta Chem Scand 12: 603-610 (1958)

10. Gripenberg J. Fungus pigments. XIII. Tramesangiun, the pigment of Trametes cinnabarina var. sanguinea. Acta Chem Scand 17: 703-708 (1963)

11. Xu C, Wang L, Cui Q, Huang Y, Liu Z, Zheng G, Goodfellow M. Neutrotolerant acidophilic Streptomyces species isolated from acidic soils in China: Streptomyces guandensis sp. nov., Streptomyces paucisporeus sp. nov., Streptomyces rubidus sp. nov. and Streptomyces yanglinensis sp. nov. Int J Syst Evol Microbiol 56: 1109-1115 (2006)

12. Sheldrick GM. SHELX-97: Programmpaket zur Lösung und Verfeinerung von Kristallstrukturen, Universität Göttingen (1997)

13. Grever MR, Shepartz SA, Chabner BA. The National Cancer Institute: cancer drug discovery and development program. Semin Oncol 19: 622-638 (1992)

14. Staneck JL, Roberts GD. Simplified approach to the identification of aerobic actinomycetes by thin-layer chromatography. Appl Microbiol 28: 226-231 (1974)

15. Williams ST, Goodfellow M, Alderson G. Genus Streptomyces Waksman and Henrici 1943, 339 ${ }^{\mathrm{AL}}$. In Bergey's Manual of Systematic Bacteriology, Vol. 4. Ed. S. T. Williams et al., pp. 2452-2492, Williams \& Wilkins,
Baltimore (1989)

16. Liu Z, Shi Y, Zhang Y, Zhou Z, Lu Z, Li W, Huang Y, Rodriguez C, Goodfellow M. Classification of Streptomyces griseus (Krainsky 1914) Waksman and Henrici 1949 and related species and the transfer of Microstreptospora cinerea to the genus Streptomyces as Streptomyces yanii sp. nov. Int J Syst Evol Microbiol 55: 1605-1610 (2005)

17. Waksman SA, Woodruff HB. Actinomyces antibioticus, a new soil organism antagonistic to pathogenic and nonpathogenic bacteria. J Bacteriol 42: 231-249 (1941)

18. Brockmann H. Die Actinomycine. Angew Chem 72: 939-947 (1960)

19. Reich E, Cerami A, Ward DC. Actinomycin. In Antibiotics. I. Mechanism of Action. Ed. D. Gottlieb \& P. D. Shaw, pp. 714-725, Springer, Berlin (1967)

20. Hollstein U. Actinomycin. Chemistry and mechanism of action. Chem Rev 74: 625-652 (1974)

21. Veselkov AN, Maleev VY, Glibin EN, Karawajew L, Davis DB. Structure-activity relation for synthetic phenoxazone drugs. Evidence for a direct correlation between DNA binding and pro-apoptotic activity. Eur J Biochem 270: 4200-4207 (2003)

22. Miyano-Kurosaki N, Kurosaki K, Hayashi M, Takaku H, Hayafune M, Shirato K, Kasuga T, Endo T, Tomoda A. 2Aminophenoxazine-3-one suppresses the growth of mouse malignant melanoma B16 cells transplanted into C57BL/8Cr Slc mice. Biol Pharm Bull 29: 2197-2201 (2006)

23. Shimamoto T, Tomoda A, Ishida R, Ohyashiki K. Antitumor effects of a novel phenoxazine derivative on human leukemia cell lines in vitro and in vivo. Clin Cancer Res 7: 704-708 (2001)

24. Shimizu S, Suzuki M, Miyazawa K, Yokoyama T, Ohyashiki K, Miyazaki K, Abe A, Tomoda A. Differentiation and apoptosis in human malignant melanoma G-361 cells induced by 2-aminophenoxazine-3-one. Oncol Rep 14: 41-46 (2005)

25. Ohnishi Y, Furusho Y, Higashi T, Chun H-K, Furihata K, Sakuda S, Horinouchi S. Structures of grixazone A and B, A-factor-dependent yellow pigments produced under phosphate depletion by Streptomyces griseus. J Antibiot 57: 218-223 (2004)

26. Friesen C, Herr I, Krammer PH, Debatin KM. Involvement of the CD95 (APO-1/Fas) receptor/ligand system in druginduced apoptosis in leukemia cells. Nat Med 2: 574-580 (1996)

27. Müller M, Wilder S, Bannasch D, Israeli D, Lehlbach K, LiWeber M, Friedman SL, Galle PR, Stremmel W, Oren M, Krammer PH. p53 activates the CD95 (APO-1/Fas) gene in response to DNA damage by anticancer drugs. J Exp Med 188: 2033-2045 (1998) 